\title{
Predominant Culturable Bacillus Species in Japanese Arable Soils and Their Potential as Biocontrol Agents
}

\author{
TAKANORI NISHIJIMA ${ }^{1 \dagger}$, KOKI TOYOTA ${ }^{1 *}$ and MASAMI MOCHIZUKI ${ }^{2}$ \\ ${ }^{1}$ Graduate School of Bio-Applications and Systems Engineering, Tokyo University of Agriculture and \\ Technology, 2-24-16, Naka-cho, Koganei, Tokyo 184-8588, Japan \\ ${ }^{2}$ Idemitsu Kosan Co. Ltd., 1280, Kami-izumi, Sodegaura, Chiba 299-0205, Japan
}

(Received October 20, 2004-Accepted December 9, 2004)

To reveal predominant culturable Bacillus species in Japanese arable soils, aerobic spore-forming bacteria were isolated from different soils in Japan and their phylogenic positions were estimated from the 16S rDNA sequences. Bacillus species were also isolated from tomato roots grown in soils for 4 weeks to estimate the difference in phylogenic positions between soil and root isolates. The number of culturable Bacillus species ranged from 6.4 to $7.4 \log$ cfu g ${ }^{-1}$ soil and 4.7 to $6.7 \mathrm{log}$ cfu g ${ }^{-1}$ root in soils and tomato roots, respectively, and the proportion of Bacillus species among total culturable bacteria ranged from $3.8 \%$ to $17.9 \%$ and $0.1 \%$ to $6.7 \%$ in soils and roots, respectively. The differences in the number and percentage of culturable Bacillus species between the soils and roots were highly significant ( $\mathrm{P}=0.0000$ and 0.0023 , respectively), indicating that Bacillus species were more predominant in soil than in root. A total of 108 isolates were characterized using the restriction fragment length polymorphism (RFLP) method and partial 16S rDNA sequences. They affiliated to 22 species including the genus Bacillus, Brevibacillus and Paenibacillus. No nitrogen fixers were isolated. The predominant species was Bacillus megaterium to which 42 isolates (39\%) belonged. Some of the species, such as Bacillus luciferensis and Brevibacillus agri, were isolated only from the tomato roots and considered to be more adapted to the rhizosphere than soil. Among 108 isolates, only one strain, N2S6, belonging to Bacillus megaterium, showed consistent antagonistic activity against the bacterial wilt of tomato caused by Ralstonia solanacearum.

Key words: Bacillus, Bacillus megaterium, Brevibacillus, Paenibacillus, rhizosphere

Spore-forming bacteria, typically Bacillus species, are one of the major types of soil bacteria ${ }^{2}$. Recently, Felske et $a l .{ }^{6,7)}$ reported that Bacillus species, especially B. benzoevorans, constitute a majority of the bacteria in Dutch soil using culture-independent and culture-dependent methods. It is known that Bacillus species produce at least 66 different antibiotics ${ }^{13)}$ and certain Bacillus strains are antagonistic to plant pathogenic fungi and bacteria and thereby function as a biocontrol agent $\mathrm{t}^{3,4,9,19,24,27)}$.

The biodiversity of the selected Bacillus species, such as culturable Bacillus species ${ }^{30)}$, B. subtilis ${ }^{26,31)}$, B. polymyxa ${ }^{17)}$,

\footnotetext{
* Corresponding author; E-mail: kokit@cc.tuat.ac.jp, Tel \& Fax: +81-42-388-7915

† Present address: Kirin Beverage Corporation, Samukawa-machi, Koza-gun, Kanagawa 253-0101, Japan
}

Paenibacillus azotofixans ${ }^{29)}$, and Paenibacillus alvei ${ }^{5)}$, has been reported. Recently, the biodiversity of Bacillus species in Dutch soil has also been studied using a molecular method $^{10)}$, revealing the dominant species to be $B$. mycoides, B. pumilus, B. benzoevorans and B. cereus. Felske et al. ${ }^{8)}$ also found that $B$. megaterium, B. benzoevorans, and Paenibacillus were the major culturable Bacillus species in soil and more than half of the Bacillus isolates might belong to new species. However, few studies have revealed the biodiversity of Bacillus species in Japanese soils. Katoh and Suzuki ${ }^{14)}$ isolated ca. 300 bacterial isolates from Japanese soils amended with cow dung and found that 102 were spore-formers. They classified 22, 13, 7 and 5 strains into $B$. megaterium, B. cereus, B. pumilus and B. sphaericus, respectively, based on phenotypic characteristics such as the 
morphology of sporangia, VP-tests and the presence of nitrate reductases, but the classification of more than $50 \%$ of the spore-formers (57 strains) remained unclear. Shintani ${ }^{32}$ ) reported on the biodiversity of indigenous Bacillus species, but targeted only nitrogen-fixers which account for a fraction of Bacillus species ${ }^{28)}$. Consequently, the biodiversity of Bacillus species in Japanese soils remains mostly unknown. The objective of this study was to isolate the predominant Bacillus species in different Japanese arable soils and estimate their biodiversity. In addition, the ability of isolates to control the bacterial wilt of tomato caused by Ralstonia solanacearum, a serious soil-borne disease in Japan, was evaluated since one of the major applications of Bacillus species in the soil environment is as a biocontrol agent.

\section{Materials and Methods}

Soils used

Arable soils ( 0 to $10 \mathrm{~cm}$ ) were collected from the Higashi-Mikawa Agricultural Research Institute, Aichi Prefecture Agricultural Research Center (Toyohashi, Aichi, Japan), Department of Fruit Vegetables, National Institute of Vegetables and Tea Science (Taketoyo, Aichi, Japan), National Agricultural Research Center ${ }^{22}$ (Tsukuba, Ibaraki), National Agricultural Research Center for Western Region (Ayabe, Kyoto, Japan), Kanagawa Prefecture Agricultural Research Institute (Hiratsuka, Kanagawa, Japan), farmland in Esashi ${ }^{20)}$ (Iwate, Japan) and Nakijin (Okinawa, Japan) and Tokyo University of Agriculture and Technology (Fuchu, Tokyo, Japan) (Table 1), and used for growing tomato plants within 3 months of the samplings.

\section{Isolation of aerobic spore-forming bacteria from soil and} tomato root

Tomato (Lycopersicon esculentum Mill. cv. Momotaro) seeds were pregerminated in a moist petri dish in the dark at $28^{\circ} \mathrm{C}$ for two days. Then, one tomato seedling was transplanted into a vinyl pot $9 \mathrm{~cm}$ in diameter containing $200 \mathrm{~g}$ of soil and grown in a climatron, adjusted to $80 \%$ relative humidity and $30^{\circ} \mathrm{C}$ with a light regime (day:night=12 h:12 $\mathrm{h}$, light intensity $=270 \mu \mathrm{mol} \mathrm{m} \mathrm{m}^{-2} \mathrm{~s}^{-1}$ ). Three pots were prepared for each soil. Hyponex fertilizer that contains NPK was added once a week to each pot to support plant growth throughout the period of incubation. Watering was performed twice a day to maintain 55\% maximum water-holding capacity (MWHC). After 4 weeks of incubation, tomato roots were carefully removed from the pots and soaked in sterile water for $10 \mathrm{~min}$. The roots were washed in sterile water three times, cut into two fragments, the upper and lower parts, and then macerated separately in a sterile mortal with pestle. Non-rhizosphere soil was collected from the pots after cultivation and $10 \mathrm{~g}$ of the soil was suspended in a $0.85 \% \mathrm{NaCl}$ solution. The root and soil suspensions were heated at $80^{\circ} \mathrm{C}$ for $10 \mathrm{~min}$ and serially diluted. Portions of appropriate dilutions $\left(10^{-2}\right.$ to $\left.10^{-4}\right)$ were spread onto $10^{-1}$ nutrient agar medium (1/10 NA). After 3 to 4 days of incubation at $30^{\circ} \mathrm{C}$, the colonies were enumerated and those with a different appearance were isolated for further characterization. The formation of spores by the isolates was confirmed by microscopic observation and spore-positive isolates were regarded as Bacillus. The total culturable bacteria were similarly enumerated using the root and soil suspensions without the heat treatment, but colony counts were made after 2 weeks of incubation.

Table 1. Characteristics of the soils used

\begin{tabular}{|c|c|c|c|c|c|c|}
\hline Site (soil name) & Soil texture & $\begin{array}{c}\text { MWHC } \\
\left(\mathrm{g} \mathrm{g}^{-1}\right)\end{array}$ & $\begin{array}{c}\mathrm{pH} \\
\left(\mathrm{H}_{2} \mathrm{O}\right)\end{array}$ & $\begin{array}{l}\text { Total C } \\
\left(\mathrm{g} \mathrm{kg}^{-1}\right)\end{array}$ & $\begin{array}{r}\text { Total N } \\
\left(\mathrm{g} \mathrm{kg}^{-1}\right)\end{array}$ & $\begin{array}{l}\mathrm{C} / \mathrm{N} \\
\text { ratio }\end{array}$ \\
\hline Esashi, Iwate (Yellow soil) & Light clay & 0.60 & 6.3 & 11.0 & 1.2 & 9.4 \\
\hline Tsukuba, Ibaraki (High-humic andosol) & Loam & 0.97 & 5.7 & 78.1 & 4.8 & 16.4 \\
\hline Fuchu, Tokyo (High-humic andosol) & Loam & 1.43 & 5.0 & 80.1 & 8.2 & 9.8 \\
\hline Hiratsuka (Gray lowland soil) & Sandy loam & 0.95 & 5.6 & 14.1 & 1.6 & 9.1 \\
\hline Hiratsuka (Low-humic andosol) & Loam & 1.30 & 5.5 & 24.5 & 2.8 & 8.9 \\
\hline Hiratsuka (High-humic andosol) & Loam & 1.30 & 5.7 & ND & ND & ND \\
\hline Toyohashi (Yellow soil) & Light clay & 0.56 & 5.3 & 9.0 & 1.1 & 8.5 \\
\hline Taketoyo (Yellow soil) & Light clay & 0.55 & 5.9 & 8.5 & 0.9 & 9.9 \\
\hline Ayabe (Brown lowland soil) & Clay loam & 0.48 & 5.3 & 6.9 & 1.0 & 7.3 \\
\hline Nakijin (Red soil) & Light clay & 0.51 & 4.2 & ND & ND & $\mathrm{ND}$ \\
\hline
\end{tabular}

ND: not determined. 


\section{Characterization of the isolates}

DNA was extracted from the purified Bacillus strains with the conventional method ${ }^{21}$ and the PCR primers $27 \mathrm{f}$ and L140123) were used to amplify the segment of bacterial 16S rDNA from nucleotide 27 to 1401 (Escherichia coli numbering ${ }^{16)}$ ). The primer L1401 added with the M13 reverse sequence was used. PCR was carried out using a basic reaction mixture containing Ex Taq buffer (Takara, Otsu, Japan), $2.5 \mathrm{mM}$ of each deoxyribonucleotide triphosphate, 2.5 U of Ex Taq (Takara), $0.2 \mathrm{mM}$ of each oligonucleotide primer and $1 \mu \mathrm{l}$ of template (purified DNA) in a total volume of $25 \mu \mathrm{l}$. The programe was $3 \mathrm{~min}$ at $94^{\circ} \mathrm{C}$; amplification for 30 cycles, each consisting of $1 \mathrm{~min}$ at $94^{\circ} \mathrm{C}, 1 \mathrm{~min}$ at $55^{\circ} \mathrm{C}$, and $1.5 \mathrm{~min}$ at $72^{\circ} \mathrm{C}$; and a final extension for $8 \mathrm{~min}$ at $72^{\circ} \mathrm{C}$. For the restriction fragment length polymorphism (RFLP) analysis, the PCR products (ca. $3 \mu \mathrm{g}$ ) were digested with $5 \mathrm{U}$ of each endonuclease HinfI, HaeIII and MspI (Takara, Otsu, Japan) and the digested products were electrophoresed in a $2 \%$ agarose gel with $0.5 \mu \mathrm{g} \mathrm{ml}^{-1}$ of ethidium bromide. RFLP analysis was done for a total of 108 isolates and separated them into different patterns. Then, direct sequencing ( 800 b.p.) of the PCR products derived from 70 isolates with different RFLP patterns and different origins was done by Hitachi Science Systems, Ltd. (Tokyo, Japan). The phylogenic position of the sequences obtained (AB111827 to AB111848) was examined using the DDBJ homology search system BLAST.

The nitrogen-fixing activity of the isolates was determined using the acetylene reduction assay ${ }^{15)}$. Individual isolates were inoculated into an air-tight vial containing semisolid Rennie's medium ${ }^{25)}$. After inoculation, $10 \%$ of the headspace was replaced with acetylene and the vials were incubated for 3 to 5 days at $28^{\circ} \mathrm{C}$. The production of ethylene was measured with a Shimadzu model GC14B gas chromatograph with an FID detector (Shimadzu Co., Kyoto, Japan).

\section{Biocontrol}

The ability of the isolates to control the bacterial wilt of tomato caused by Ralstonia solanacearum was examined using the yellow soil (Esashi). Two hundreds gram of soil inoculated with $R$. solanacearum YU1Rif43 ${ }^{34)}$ at a density of $5 \times 10^{6} \mathrm{cfu} \mathrm{g}^{-1}$ soil was put into a vinyl pot $9 \mathrm{~cm}$ in diameter. Then, six tomato seedlings were transplanted and $1 \mathrm{ml}$ of the bacterial culture in $10^{-1}$ nutrient broth was poured around the seedlings. Growth conditions for tomato plants were the same as above. A disease index was recorded periodically for 28 days on the following basis: 0 ; no wilting,
$1 ; 0$ to $25 \%$ of plant showing wilting, $2 ; 26$ to $50 \%, 3: 51$ to $75 \%, 4: 76$ to $100 \%$. After the first screening, the isolates which showed apparent suppressive effects were re-tested using duplicate pots. One isolate which showed consistent suppressive effects in the first and second screenings was used in further experiments.

Effect of the addition of poultry manure compost (PMC), the disease-suppressive effect of which was previously reported $^{12)}$, on the suppressive effect of the Bacillus strain was examined. PMC was added to the soil at a ratio of $10 \%$ $(\mathrm{v} / \mathrm{v})$, corresponding to $5 \mathrm{~g}$ of dry weight compost in $1 \mathrm{~kg}$ of soil, and mixed thoroughly. Methods for inoculating the pathogen and growing the tomato plants were described previously. Two pots were prepared per treatment and the experiment was repeated three times.

\section{Results and Discussion}

Number of total culturable bacteria and Bacillus species in soil and root

The numbers of total culturable bacteria in the soils and roots ranged from 7.4 to $8.7(8.0 \pm 0.5)$ and 6.7 to 8.7 (7.6 \pm 0.5$) \log$ cfu g $^{-1}$, respectively (Table 2 ). Those of sporeforming bacteria, regarded as Bacillus species, in the soils and roots were significantly $(\mathrm{P}=0.0303)$ different depending on the soils used, ranging from 6.3 to $7.4(6.8 \pm 0.3)$ and 4.7 to $6.7(5.5 \pm 0.5) \log$ cfu g $^{-1}$, respectively. Numbers of Bacillus species were significantly larger in the root tip $(5.7 \pm 0.5$ Log cfu g ${ }^{-1}$ root) than root base $\left(5.3 \pm 0.3 \mathrm{Log}_{\text {cfu }}{ }^{-1}\right.$ root $)$. The proportion of Bacillus as a percentage of the total number of culturable bacteria ranged from $3.8 \%$ to $27.8 \%$ (Mean $\pm \mathrm{SD}=8.7 \pm 8.6 \%$ ) in the soils and $0.1 \%$ to $6.7 \%$ (Mean $\pm \mathrm{SD}=1.5 \pm 2.0 \%$ ) in the root tip and base and the difference was highly significant $(\mathrm{P}=0.0023)$. There was no significant difference in this value between the root tip and base.

Garbeva et al. ${ }^{10)}$ reported that numbers of Bacillus species in the soil and rhizosphere of maize ranged from 4.7 to 5.7 and 5.2 to $5.9 \log$ cfu g $^{-1}$, respectively. According to Seldin et al. $^{28)}$, numbers of aerobic spores in Brazilian soils ranged from 6.0 to $6.2 \log \mathrm{cfu} \mathrm{g}^{-1}$. The numbers of Bacillus species observed in the present study were similar to those in the previous studies, but were higher in the soils than in the roots, unlike in Garbeva et al. ${ }^{10)}$, and the reason for this remains unclear.

Characterization of predominant Bacillus species in soil and root

From the plates with the highest dilutions, several colo- 
Table 2. The number of total culturable and spore-forming bacteria in soils and roots of tomato grown in the soils

\begin{tabular}{|c|c|c|c|}
\hline Soil & $\begin{array}{l}\text { Total culturable bacteria } \\
\text { Log cfu g }{ }^{-1} \text { root or soil }\end{array}$ & $\begin{array}{l}\text { Spore-forming bacteria } \\
\text { Log cfu } \mathrm{g}^{-1} \text { root or soil }\end{array}$ & Ratio (\%) \\
\hline \multicolumn{4}{|l|}{ Yellow soil (Esashi) } \\
\hline Tip of root & 8.4 & 6.1 & 0.46 \\
\hline Base of root & 7.8 & 5.6 & 0.68 \\
\hline Soil & 8.6 & 7.4 & 5.2 \\
\hline \multicolumn{4}{|c|}{ High humic andosol (Tsukuba) } \\
\hline Tip of root & 8.0 & 5.2 & 0.1 \\
\hline Base of root & 7.7 & 5.2 & 0.3 \\
\hline Soil & 7.8 & 6.4 & 3.8 \\
\hline \multicolumn{4}{|c|}{ High humic andosol (Fuchu) } \\
\hline Tip of root & 7.4 & 5.8 & 2.6 \\
\hline Base of root & 6.7 & 5.4 & 6.7 \\
\hline Soil & 7.4 & 6.6 & 17.9 \\
\hline \multicolumn{4}{|c|}{ High humic andosol (Hiratsuka) } \\
\hline Tip of root & 8.4 & 5.8 & 0.33 \\
\hline Base of root & 7.9 & 5.8 & 1.0 \\
\hline Soil & 7.5 & 6.3 & 6.4 \\
\hline \multicolumn{4}{|c|}{ Low humic andosol (Hiratsuka) } \\
\hline Tip of root & 8.7 & 5.8 & 0.1 \\
\hline Base of root & 7.3 & 5.3 & 1.1 \\
\hline Soil & 8.0 & 6.7 & 4.3 \\
\hline \multicolumn{4}{|c|}{ Grey lowland soil (Hiratsuka) } \\
\hline Tip of root & 7.9 & 6.7 & 6.4 \\
\hline Base of root & 6.9 & 5.4 & 2.9 \\
\hline Soil & 7.6 & 7.1 & 27.8 \\
\hline \multicolumn{4}{|c|}{ Yellow soils (Taketoyo) } \\
\hline Tip of root & 7.3 & 5.6 & 2.0 \\
\hline Base of root & 7.5 & 5.4 & 0.8 \\
\hline Soil & 8.2 & 6.8 & 4.1 \\
\hline \multicolumn{4}{|c|}{ Brown lowland soil (Ayabe) } \\
\hline Tip of root & 7.0 & 5.1 & 1.2 \\
\hline Base of root & 7.1 & 4.7 & 0.41 \\
\hline Soil & 7.8 & 6.7 & 8.0 \\
\hline \multicolumn{4}{|l|}{ Red soil (Nakijin) } \\
\hline Tip of root & 7.8 & 5.1 & 0.21 \\
\hline Base of root & 7.6 & 5.2 & 0.44 \\
\hline Soil & 8.7 & 6.8 & 1.2 \\
\hline
\end{tabular}

nies with different appearances were isolated. An RFLP analysis was conducted for a total of 108 isolates which were then divided based on different patterns (data not shown). Next, the $16 \mathrm{~S}$ rDNA of 70 isolates with different RFLP patterns and different origins were partially sequenced. All the sequence results showed more than $98.9 \%$ identity to known species, except for the one closest to Paenibacillus agarexedens with $96.9 \%$ (Table 3). The closest species of 42 isolates were B. megaterium, recovered from a wide range of soils and roots, indicating that $B$. megaterium may be the predominant Bacillus species in Japanese arable soils. Strains of $B$. cereus (14 isolates) and $B$. niacini (6 isolates) were also frequently isolated from both the soils and roots. Eight and six isolates belonging to B. luciferensis and Brevibacillus agri, respectively, were obtained and all were from the roots. Four B. marisflavi and three $B$. firmus isolates were also recovered from only the roots. Strains of several species, including B. sphaericus 
Table 3. Phylogenic position of Bacillus species, based on RFLP analysis and 16S rDNA sequencing, isolated from different Japanese soils and roots of tomato grown in the soils

\begin{tabular}{|c|c|c|c|c|c|c|c|c|c|c|c|c|c|c|c|c|c|}
\hline \multirow[b]{2}{*}{ Nearest species } & \multicolumn{8}{|c|}{ Soil } & \multicolumn{8}{|c|}{ Root } & \multirow[b]{2}{*}{ Total } \\
\hline & $\begin{array}{l}\text { Yellow } \\
\text { soil } \\
\text { (Esashi) }\end{array}$ & $\begin{array}{c}\text { High } \\
\text { humic } 1 \\
\text { andosol } \\
\text { (Tsukuba) }\end{array}$ & $\begin{array}{l}\text { Grey } \\
\text { lowland } \\
\text { soil } \\
\text { (Hira- } \\
\text { tsuka) }\end{array}$ & $\begin{array}{l}\text { Low } \\
\text { humic } \\
\text { andosol } \\
\text { (Hira- } \\
\text { tsuka) }\end{array}$ & $\begin{array}{l}\text { Yellow } \\
\text { soil } \\
\text { (Toyo- } \\
\text { hashi) }\end{array}$ & $\begin{array}{l}\text { Yellow } \\
\text { soil } \\
\text { (Take- } \\
\text { toyo) }\end{array}$ & $\begin{array}{l}\text { Brown } \\
\text { lowland } \\
\text { soil } \\
\text { (Ayabe) }\end{array}$ & $\begin{array}{l}\text { Red soil } \\
\text { (Nakijin) }\end{array}$ & $\begin{array}{l}\text { Yellow } \\
\text { soil } \\
\text { (Esashi) }\end{array}$ & $\begin{array}{c}\text { High } \\
\text { humic } \\
\text { andosol } \\
\text { (Tsukuba) }\end{array}$ & $\begin{array}{l}\text { Grey } \\
\text { lowland } \\
\text { soil } \\
\text { (Hira- } \\
\text { tsuka) }\end{array}$ & $\begin{array}{l}\text { Low } \\
\text { humic } \\
\text { andosol } \\
\text { (Hira- } \\
\text { tsuka) }\end{array}$ & $\begin{array}{l}\text { Yellow } \\
\text { soil } \\
\text { (Toyo- } \\
\text { hashi) }\end{array}$ & $\begin{array}{l}\text { Yellow } \\
\text { soil } \\
\text { (Take- } \\
\text { toyo) }\end{array}$ & $\begin{array}{l}\text { Brown } \\
\text { lowland } \\
\text { soil } \\
\text { (Ayabe) }\end{array}$ & $\begin{array}{l}\text { Red soil } \\
\text { (Nakijin) }\end{array}$ & \\
\hline B. bataviensis & $1(1)$ & & & & & $2(2)$ & & & & & & & & $2(1)$ & & & $5(4)$ \\
\hline B. cereus & $2(1)$ & $1(1)$ & & & & & & & & $3(1)$ & $5(2)$ & $2(2)$ & & $1(1)$ & & & $14(8)$ \\
\hline B. drentensis & & & & $1(1)$ & & & & $1(1)$ & & & & & & & & & $2(2)$ \\
\hline B. firmus & & & & & & & & & & & $3(3)$ & & & & & & $3(3)$ \\
\hline B. fumarioli & & & & & & & & & & & & & & $1(1)$ & & & $1(1)$ \\
\hline B. gelatini & & & & & & $3(0)$ & & & & & & & & $1(1)$ & & & $4(1)$ \\
\hline B. luciferensis & & & & & & & & & $1(1)$ & & & & $4(1)$ & $2(1)$ & & $1(1)$ & $8(4)$ \\
\hline B. macroides & & & & & & & & & & & & & & $1(1)$ & & & $1(1)$ \\
\hline B. marisflavi & & & & & & & & & & & & $3(1)$ & & & & $1(1)$ & $4(2)$ \\
\hline B. megaterium & $3(0)$ & $1(1)$ & & $2(1)$ & & $5(3)$ & $4(1)$ & $2(1)$ & $6(2)$ & $5(5)$ & $3(3)$ & $1(1)$ & $3(3)$ & $3(1)$ & $1(0)$ & $3(0)$ & $42(22)$ \\
\hline B. mycoides & & $2(2)$ & & & & & & & & & & & & & & & $2(2)$ \\
\hline B. niacini & & & & $1(1)$ & & $1(1)$ & $1(1)$ & & & & & & & $3(2)$ & & & $6(5)$ \\
\hline B. pumilus & & & & & & & & $1(1)$ & & $1(1)$ & & & & $1(1)$ & & & $3(3)$ \\
\hline B. simplexs & & & & & & & & & & & $1(1)$ & & & & & & $1(1)$ \\
\hline B. sphaericus & & & & & & & & & & $1(1)$ & & & & $1(1)$ & & & $2(2)$ \\
\hline B. subtilis & & & & & & & & & & & & & & $1(1)$ & & & $1(1)$ \\
\hline Brevib. agri & & & & & & & & & & & $3(3)$ & & $2(2)$ & $1(1)$ & & & $6(6)$ \\
\hline Brevib. choshinensis & & & & $1(1)$ & & & & & & & & & & & & & $1(1)$ \\
\hline P. agarexedens & & & & & & & & & & & $1(1)$ & & & & & & $1(1)$ \\
\hline P. pabli & & & & & & & & & & & & & & $1(1)$ & & & $1(1)$ \\
\hline Total & $6(2)$ & $4(4)$ & ND & $5(4)$ & ND & $11(6)$ & $5(2)$ & $4(3)$ & $7(3)$ & $10(8)$ & $16(13)$ & $6(4)$ & $9(6)$ & $19(14)$ & $1(0)$ & $5(2)$ & $108(70)$ \\
\hline
\end{tabular}

Numbers in the table show total numbers of the isolates belonging to the respective species after the RFLP analysis. ( ): the number of isolates sequenced. ND: not determined. B.: Bacillus, Brevib.: Brevibacillus, P.: Paenibacillus

and B. fumarioli, were isolated from only the roots, but their isolation frequency was only one or two, making difficult a sound interpretation. $\chi^{2}$ analysis $(P=0.05)$ suggested that $B$. luciferensis were adapted to rhizosphere rather than soil, although Seldin et al. ${ }^{29)}$ reported the presence of two subgroups, one in nonrhizosphere soil and one in rhizosphere, within a single species, Paenibacillus azotofixans.

Garbeva et al. ${ }^{10)}$ have revealed the diversity of Bacillus species in soil using the culture-independent method, i.e. to extract community DNA, to amplify the 16S rDNA specific to Bacillus species and then to sequence it. In their study, 8 different groups (B. cereus, B. mycoides, B. megaterium, $B$. subtilis, B. pumilus, B. benzoevorans, B. niacini/B. lentus, and Paenibacillus species) were identified from 3 kinds of soil managed differently. In spite that the present study targeted only culturable forms of Bacillus species in soil and root, the isolates obtained could be categorized into 7 out of the 8 groups (no B. benzoevorans). In addition, strains of some other species, such as $B$. bataviensis, $B$. dretensis and $B$. luciferensis, were isolated in this study, but not in their study. B. bataviensis and B. dretensis are novel species reported by Heyrman et al. ${ }^{11)}$ who successfully isolated these Bacillus lineages from soil using only a non-cultural method. Brevibacillus strains were not obtained in their study, but 7 isolates belonged to Brevibacillus species in the present study. This is because the specific primers, BacF and BacR, used by Garbeva et al. did not amplify the DNA of Brevibacillus species. The total of 108 isolates determined in this study was comparable to the 115 clones in Garbeva's study, indicating that even culturable Bacillus species possess quite a diverse species composition. This could be due to the result that more kinds of soils ( 8 soils) were used, or due to the different medium and different isolation conditions.

Felske et al. ${ }^{8)}$ tried to isolate novel Bacillus-related lineages from soil. They isolated 401 Bacillus stains and found 
that ca. $40 \%$ belonged to known species with more than $97 \%$ sequence identity, but ca. $60 \%$ did not. In the present study, all the 70 isolates sequenced, except for one $(96.9 \%)$, showed more than $98.9 \%$ sequence identity to one of the species listed in Table 3. In the present study, strains of $B a-$ cillus species were isolated after heat treatment of the soil suspension like in most studies, but heat treatment was not done in Felske's study, resulting in less bias in the isolation procedure. This could be significant, but the exact influence is not clear. They revealed that the major constituents of $\mathrm{Ba}$ cillus detected were $B$. niacini-relatives (21.9\%), unknown Paenibacillus species (16.0\%), Paenibacillus species $(12.5 \%)$ and $B$. megaterium (10.0\%). The higher frequency of $B$. megaterium and B. niacini-relatives is consistent with our study.

McCaig et al. ${ }^{18)}$ isolated strains of $B$. macroides (sequence similarity $99.1 \%$ ) and B. insolitus (92.5\%) as the major culturable bacteria in Scottish soil. An isolate closely related to $B$. macroides was also obtained in the present study. Siciliano and Germida ${ }^{33)}$ studied the taxonomic diversity of bacteria associated with the roots of Brassica napus, revealing that Bacillus species accounted for 43 of 437 isolates identified by FAME analysis and the dominant Bacillus species were B. megaterium (16 isolates), B. pumilus (10) and B. brevis (5). The fact that $B$. megaterium was the most frequently isolated species from roots was consistent with the present study.

The nitrogen-fixing activity of all the isolates was tested using the acetylene reduction assay, but none of them showed a positive reaction, suggesting that nitrogen-fixing Bacillus species like B. polymyxa and B. azotoficans were not dominant Bacillus species in the soils. According to a study by Seldin et al. ${ }^{28)}$, B. polymyxa constituted 0.2 to $2 \%$ of all Bacillus species. This relatively small ratio might result in no isolates of nitrogen-fixing Bacillus species. Several authors have isolated nitrogen-fixing Bacillus species using anaerobic culture and therefore, such species could have been isolated if anaerobic conditions had been used in this study.

\section{Biocontrol ability of the Bacillus species}

All the isolates (108) obtained in this study were tested for their ability to suppress the bacterial wilt of tomato in in vitro pot experiments. Ten isolates tended to decrease the disease incidence in the 1 st screening, but 9 did not show any suppressive effects in the 2nd screening (data not shown). Therefore, a majority of Bacillus species in soil may not be antagonistic to the bacterial wilt caused by $R$. solanacearum. Only one isolate, designated B. megaterium
N2S6, consistently reduced the disease incidence in 7 independent experiments (Fig. 1a). Isolates belonging to $B$. megaterium were most frequently obtained (42 out of 108), but only strain N2S6 was antagonistic to bacterial wilt. Many antagonists, including $P$. fluorescens and B. subtilis, useful for suppressing soil-borne plant pathogens have been reported ${ }^{1,35)}$, but this is the first report in Japan of a $B$. megaterium strain exhibiting biocontrol to our knowledge.

To enhance the biocontrol shown by the N2S6 strain, the use of poultry manure compost (PMC), the disease-suppressive effect of which was previously reported ${ }^{12)}$, was examined. The disease incidence decreased with the application of PMC and then further with strain N2S6 (Fig. 1b). Nakasaki et al. ${ }^{19)}$ found that compost from grass clippings suppressed Rhizoctonia patch disease on the inoculation of $B$. subtilis N4. This study demonstrated that the suppressive effect of PMC was enhanced by the inoculation of $B$. megaterium $\mathrm{N} 2 \mathrm{~S} 6$.
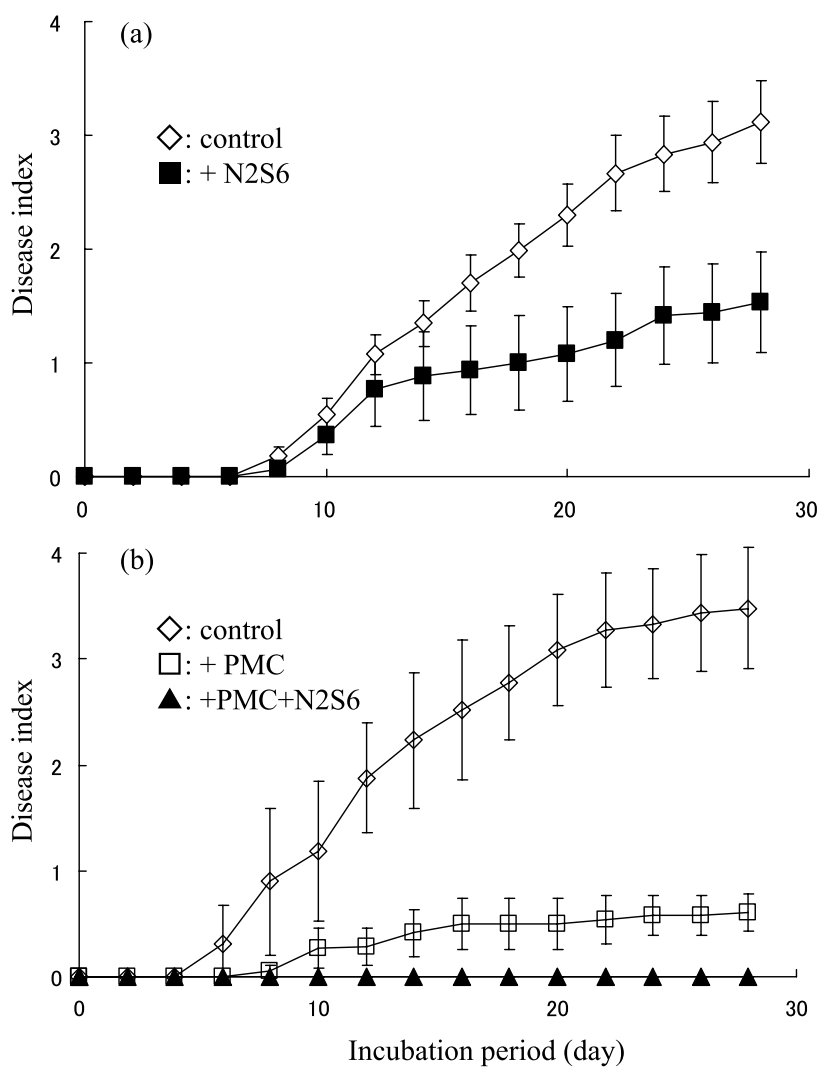

Fig. 1. Effect of inoculation of B. megaterium N2S6 and application of poultry manure compost (PMC) on the disease index of the bacterial wilt of tomato grown in yellow soil (Iwate). (a) a single inoculation of $\mathrm{N} 2 \mathrm{~S} 6$ : mean $\pm \mathrm{SD}$ (seven independent experiments), (b) a combination of $\mathrm{N} 2 \mathrm{~S} 6$ and $\mathrm{PMC}$ : mean $\pm \mathrm{SD}$ (three independent experiments) 


\section{Acknowledgments}

The authors thank Itoh, S. and Takahashi, S., National Agricultural Research Center, Ikeda, J., Hori, K. and Suga, Y., National Agricultural Research Center for the Western Region, Yamada, R., Ogino, K. and Imagawa, M., Aichi Prefectural Agricultural Research Center, Uehara, Y. and Nakano, A., National Institute of Vegetables and Tea Science, Matsumura, S. and Nishimura, T., Tokyo University of Agriculture and Technology, Izu, S. and Doi, S., Idemitsu Kosan Co. Ltd. and Fujiwara, S. and Watanabe, S., Kanagawa Prefectural Agricultural Research Institute, for their assistance in soil sampling and information on the management history.

\section{References}

1) Alabouvette, C., H. Hoeper, P. Lemanceau and C. Steinberg. 1997. Soil suppressiveness to disease induced by soilborne plant pathogens. Soil Biochem. 9: 371-413.

2) Alexander, M. 1977. Introduction to soil microbiology. Academic Press, New York, N.Y.

3) Bennett, A.J., C. Leifert and J.M. Whipps. 2003. Survival of the biocontrol agents Coniothyrium minitans and Bacillus subtilis MBI 600 introduced into pasteurised, sterilised and non-sterile soils. Soil Biol. Biochem. 35: 1565-1573.

4) Cook, R.J. and K.F. Baker. 1983. The nature and practice of biological control of plant pathogens. The American Phytopathological Society, St. Paul, Minnesota.

5) Djordjevic, S.P., W.A. Forbes, L.A. Smith and M.A. Hornitzky. 2000. Genetic and biochemical diversity among isolates of Paenibacillus alvei cultured from Australian honeybee (Apis mellifera) colonies. Appl. Environ. Microbiol. 66: 1098-1106.

6) Felske, A.D.M., A. Wolterink, R. van Ris and A.D.L. Akkermans. 1998. Phylogeny of the main bacterial 16S rRNA sequences in Drentse A grassland soils (the Netherlands). Appl. Environ. Microbiol. 64: 871-879.

7) Felske, A.D.M., A. Wolterink, R. van Ris, W.M. de Vos and A.D.L. Akkermans. 1999. Searching for predominant soil bacteria: $16 \mathrm{~S}$ rDNA cloning versus strain cultivation. FEMS Microbiol. Ecol. 30: 137-145.

8) Felske, A.D.M., J. Heyrman, A. Balcaen and P. de Vos. 2003. Multiplex PCR screening of soil isolates for novel Bacillus-related lineages. J. Microbiol. Methods 55: 447-458.

9) Ferreira, J.H.S., F.N. Matthee and A.C. Thomas. 1991. Biological control of Eutypa lata on grapevine by an antagonistic strain of Bacillus subtilis. Phytopathology 81: 283-287.

10) Garbeva, P., J.A. van Veen and J.D. van Elsas. 2003. Predominant Bacillus spp. in agricultural soil under different management regimes detected via PCR-DGGE. Microb. Ecol. 45: 302-316.

11) Heyrman, J., B. Vanparys, N.A. Logan, A. Balcaen, M. Rodriguez-Diaz, A. Felske and P. de Vos. 2004. Bacillus novalis sp. nov., Bacillus vireti $\mathrm{sp}$. nov., Bacillus soli $\mathrm{sp}$. nov., Bacillus bataviensis sp. nov. and Bacillus drentensis sp. nov., from the Drentse A grasslands. Int. J. Syst. Evol. Microbiol. 54: 47-57.

12) Islam, MD.T. and K. Toyota. 2004. Suppression of bacterial wilt of tomato by Ralstonia solanacearum using organic matter amendments and possible mechanisms. Microbes Environ. 19: 53-60.

13) Katz, E. and A.C. Demain. 1977. The peptide antibiotics of Bacillus: chemistry, biogenesis, and possible functions. Bacteriol. Rev. 41: 449-474.

14) Katoh, K. and T. Suzuki. 1979. Microflora of animal wastes applied soils. Bull. Natl. Agr. Res. Inst. B30: 73-135 (in Japanese with English summary).

15) Knowles, R. and W.L. Barraquio. 1994. Free-living dinitrogenfixing bacteria, p. 179-197. In Soil Science Society of America (ed.), Methods of Soil Analysis, Part 2-Microbiological and Biochemical Properties. Soil Science Society of America, Madison, Wisconsin.

16) Lane, D.J. 1991. 16S/23S rRNA sequencing, p. 115-175. In E. Stackebrandt and M. Goodfellow (ed.), Nucleic Acid Techniques in Bacterial Systematics. Chichester, Wiley.

17) Mavingui, P., G. Laguerre, O. Berge and T. Heulin. 1992. Genetic and phenotypic diversity of Bacillus polymyxa in soil and in the wheat rhizosphere. Appl. Environ. Microbiol. 58: 1894-1903.

18) McCaig, A.E., S.J. Grayston, J.I. Prosser and L.A. Glover. 2001. Impact of cultivation on characterisation of species composition of soil bacterial communities. FEMS Microbiol. Ecol. 35: 37-48.

19) Nakasaki, K., S. Hiraoka and H. Nagata. 1998. A new operation for producing disease-suppressive compost from grass clippings. Appl. Environ. Microbiol. 64: 4015-4020.

20) Nerome M., K. Toyota, T.MD. Islam, T. Nishijima, T. Matsuoka, K. Sato and Y. Yamaguchi. 2005. Suppression of bacterial wilt of tomato by incorporation of municipal biowaste charcoal. Soil Microorganisms, (in press), (in Japanese with English summary).

21) Nihondojyobiseibutsugakkaihen. 1992. Dojyobiseibutsujikkenhou, pp. 163-172, Yokendo, Tokyo, Japan (in Japanese).

22) Nishio, T., X. Li and M. Komada. 2002. Comparison of fate of nitrogen applied to 4 different kinds of soils with particular reference to denitrification. Soil Sci. Plant Nutr. 48: 307-313.

23) Nubel, U., B. Engelen, A. Felske, J. Snaidr, A. Wieshuber, R.I. Amann, W. Ludwig and H. Backhaus. 1996. Sequence heterogeneities of genes encoding $16 \mathrm{~S}$ rRNAs in Paenibacillus polymyxa detected by temperature gradient gel electrophoresis. J. Bacteriol. 178: 5636-5643.

24) Phae, C.G., M. Sasaki, M. Shoda and H. Kubota. 1990. Characteristics of Bacillus subtilis isolated from composts suppressing phytopathogenic microorganisms. Soil Sci. Plant Nutr. 36: 575586.

25) Rennie, R.J. 1981. A single medium for the isolation of acetylene-reducing (dinitrogen-fixing) bacteria from soils. Can. J. Microbiol. 27: 8-24.

26) Reva, O.N., C. Dixelius, J. Meijer and F.G. Priest. 2004. Taxonomic characterization and plant colonizing abilities of some bacteria related to Bacillus amyloliquefaciens and Bacillus subtilis. FEMS Microbiol. Ecol. 48: 249-259.

27) Ryder, M.H., Z. Yan, T.E. Terrace, A.D. Rovira, W. Tang and R.L. Correll. 1999. Use of strains of Bacillus isolated in China to suppress take-all and rhizoctonia root rot, and promote seedling growth of glasshouse-grown wheat in Australian soils. Soil Biol. Biochem. 31: 19-29.

28) Seldin L., J.D. van Elsas and E.G.C. Penido. 1983. Bacillus nitrogen fixers from Brazilian soils. Plant Soil 70: 243-255.

29) Seldin, L., A.S. Rosard, D.W. da Cruz, A. Nobrega, J.D. van Elsas and E. Paiva. 1998. Comparison of Paenibacillus azotofixans strains isolated from rhizoplane, rhizosphere, and non-root-asso- 
ciated soil from maize planted in two different Brazilian soils. Appl. Environ. Microbiol. 64: 3860-3868.

30) Sessitsch, A., F.-Y. Kan and U. Pfeifer. 2003. Diversity and community structure of culturable Bacillus spp. populations in the rhizospheres of transgenic potatoes expressing the lytic peptide cecropin B. Appl. Soil Ecol. 22: 149-158.

31) Shaver, Y.J., M.L. Nagpal, R. Rudner, L.K. Nakamura, K.F. Fox and A. Fox. 2002. Restriction fragment length polymorphism of rRNA operons for discrimination and intergenic spacer sequences for cataloging of Bacillus subtilis sub-groups. J. Microbiol. Methods 50: 215-223.

32) Shintani, Y. 1999. Nitrogen-fixing spore-forming aerobic bacterial isolated from the rhizosphere of some gramineous plants in western Japan. Microbes Environ. 14: 55-62.
33) Siciliano, S.D. and J.J. Germida. 1999. Taxonomic diversity of bacteria associated with the roots of field-grown transgenic Brassica napus cv. Quest, compared to the non-transgenic B. napus cv. Excel and B. rapa cv. Parkland. FEMS Microbiol. Ecol. 29: 263-272.

34) Toyota, K. and M. Kimura. 1996. Growth of the bacterial wilt pathogen Pseudomonas solanacearum introduced into soil colonized by individual soil bacteria. Soil Biol. Biochem. 28: 14891494.

35) Weller, D.M. and L.S. Thomashow. 1994. Current challenges in introducing beneficial microorganisms into the rhizosphere, p. 118. In F. O'Gara, D.N. Dowling and B. Boesten (ed.), Molecular Ecology of Rhizosphere Microorganisms. VCH, Weinheim, Germany. 